\title{
MET NM_000245.3:c.3274G>A
}

National Cancer Institute

\section{Source}

National Cancer Institute. MET NM 000245.3:C.3274G>A. NCI Thesaurus. Code

C162291.

A nucleotide substitution at position 3274 of the coding sequence of the MET gene where guanine has been mutated to adenine. 